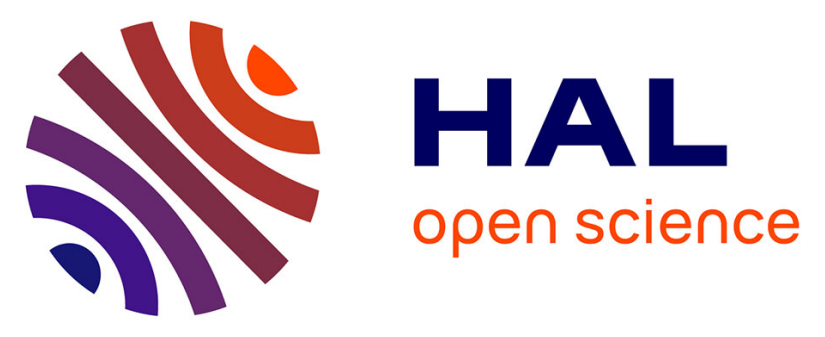

\title{
Prospective association between breast cancer risk and an individual dietary index based on the British Food Standards Agency nutrient profiling system
}

Mélanie Deschasaux, Chantal Julia, Laurent Zelek, Emmanuelle Kesse-Guyot, Véronique Gourlet, Lucie Lecuyer, Caroline Méjean, Pauline Ducrot, Sandrine Peneau, Paule Latino-Martel, et al.

\section{To cite this version:}

Mélanie Deschasaux, Chantal Julia, Laurent Zelek, Emmanuelle Kesse-Guyot, Véronique Gourlet, et al. Prospective association between breast cancer risk and an individual dietary index based on the British Food Standards Agency nutrient profiling system. San Antonio Breast Cancer Symposium, Dec 2016, San Antonio, United States. pp.2 [abstract], 10.1158/1538-7445.SABCS16-P4-13-01 . hal01605983

\section{HAL Id: hal-01605983 https://hal.science/hal-01605983}

Submitted on 2 Jun 2020

HAL is a multi-disciplinary open access archive for the deposit and dissemination of scientific research documents, whether they are published or not. The documents may come from teaching and research institutions in France or abroad, or from public or private research centers.
L'archive ouverte pluridisciplinaire HAL, est destinée au dépôt et à la diffusion de documents scientifiques de niveau recherche, publiés ou non, émanant des établissements d'enseignement et de recherche français ou étrangers, des laboratoires publics ou privés. 


\section{San Antonio Breast Cancer Symposium}

Publication Number: P4-13-01

Title: Prospective association between breast cancer risk and an individual dietary index based on the British Food Standards Agency nutrient profiling system

Deschasaux M, Julia C, Zelek L, Kesse-Guyot E, Gourlet V, Lécuyer L, Méjean C, Ducrot P, Peneau S, Latino-Martel P, Fézeu L, Fassier P, Hercberg S and Touvier M. Sorbonne Paris Cité Epidemiology and Statistics Research Center (CRESS), Inserm U1153, Inra U1125, Cnam, Paris 13 University, Nutritional Epidemiology Research Team (EREN), Bobigny, France; Avicenne Hospital, APHP, Bobigny, France and Avicenne Hospital, APHP, Bobigny, France.

Body: Background: The Food Standards Agency Nutrient Profiling System (FSA-NPS) constitutes the basis for the Five-Colour Nutrition Label suggested in France to be put on the front-of-pack of food products. At the individual level, a dietary index (FSA-NPS DI) has been derived and validated and corresponds to a weighted mean of all FSA-NPS scores of foods usually consumed by the individual, reflecting the nutritional quality of his/her diet. Our aim was to investigate the association between the FSA-NPS DI and breast cancer risk in a large cohort.

Methods: This prospective study included 46,864 women aged over 35y from the NutriNet-Santé cohort (2009-2015) who completed at least three $24 \mathrm{~h}$ dietary records during the first $2 \mathrm{y}$ of follow-up (median follow-up: 4.0y). 555 incident breast cancers were diagnosed. FSA-NPS DI was computed for each subject using the following nutrient content for $100 \mathrm{~g}$ of each foods and beverages consumed: energy, total sugar, saturated fatty acid, sodium, fruits and vegetables (\%), fibres and proteins. Higher values of the FSA-NPS DI correspond to a lower nutritional quality of the diet. Associations were characterized by multivariate Cox proportional hazards models.

Results: The FSA-NPS DI was directly associated with breast cancer risk ( $\mathrm{HR}_{1 \text {-point increment }}=1.06$ (1.02-1.11), $\mathrm{P}$-trend=0.005; $H R_{Q 5 v s . Q 1}=1.52(1.11-2.08)$, P-trend=0.002). These associations were similar after the exclusion of cases diagnosed during the first year of follow-up.

Conclusions: In this prospective study, a higher FSA-NPS individual score was associated with an increased breast cancer risk. These results suggested that unhealthy food choices may be associated with a $52 \%$ increase in breast cancer risk (FSA-NPS DI $\geq 7.7$ (Q5) vs. $<4.1$ (Q1)), supporting the public health relevance of developing front-of-pack nutrition labels based on this score. 